\title{
The alteration of the sensory consciousness of the Self as a trigger mechanism determining a craving in substance abuse and eating disorders. A single-case study
}

\author{
Zmiana sensorycznej świadomości Jaźni jako czynnik wyzwalający mechanizmy głodu
} substancji psychoaktywnych i zaburzeń odżywiania. Analiza przypadku

Supervisor of Clinical Activity of "Residenza Tuberose," Protected Therapeutic Community for Adolescents and Young Adults, Rome, Italy

Correspondence: Emanuela Atzori, Viale dei Quattro Venti, 250, 00152, Rome, Italy, e-mail: emanuela.atzori66@gmail.com

\begin{abstract}
Introduction: Difficulty in perceiving and providing an appropriate cognitive interpretation of the stimuli originating from the body, combined with a difficulty in perceiving and describing emotions correctly, has been identified for a long time in patients with substance abuse and eating disorders. This first eidetic nucleus has been indissolubly linked to the difficulty in perceiving others as intelligible objects. Objective: The objective of this paper is to further the research into possible psychological factors underlying the deficit in the sensory consciousness of the Self, in which the internal image of the body and the person does not have a solid mental representation. In consequence, the relationship between the psychological and the somatic part of the Self seems vulnerable to psychopathological break-down. In this paper, sensation seeking is construed as an attempt to overcome an interoceptive, an exteroceptive and a proprioceptive difficulty. Craving and repetition of pathological behaviour is interpreted here as an attempt to reconstruct the body scheme in a Self which is fragmented or at a risk of fragmentation through the memory of the sensations experienced using an inanimate object, food or psychotropic substances. In relationship with them an increase in symbolic capability is impossible, as it is achievable only through a human relationship. Method: To corroborate this hypothesis, I undertook a single-case study of comorbidity with substance abuse and eating disorders. This research describes the application of an integrated method in which the use of standardised instruments as MMPI-2 (Minnesota Multiphasic Personality Inventory), EDI-2 (Eating Disorder Inventory) and TAS-20 (Toronto Alexithymia Scale), tested and retested in a frame time of 6 years, is accompanied by the interpretation of dreams, based on the theoretical platform of Massimo Fagioli’s Human Birth Theory, in order to achieve a greater diagnostic certainty as well as more definite therapeutic treatment. Results: Quantitatively, the patient's positive reaction to psychotherapy is expressed by changes in the test-retest scale scores, while qualitatively the patient's positive reaction to psychotherapy is expressed through changes in the dream activity. Conclusion: The results obtained encourage successive controls of the interpretative hypothesis about craving proposed in this paper with further studies.
\end{abstract}

Keywords: craving, sensory consciousness of the Self, psychotherapy, Human Birth Theory

Streszczenie U osób nadużywających substancji psychoaktywnych oraz u pacjentów cierpiących na zaburzenia odżywiania już dawno zaobserwowano trudności w prawidłowym odbiorze i adekwatnej interpretacji poznawczej bodźców pochodzących z wnętrza ciała oraz w prawidłowym postrzeganiu i opisywaniu własnych emocji. Pierwsze jądro ejdetyczne (pierwotne, rdzenne doświadczenie wzrokowe) zostało ściśle powiązane z trudnościami w postrzeganiu innych jako zrozumiałych obiektów. Cel: Celem artykułu jest dalsze poszukiwanie potencjalnych czynników psychologicznych leżących u podstaw deficytu świadomości sensorycznej Jaźni (self), wskutek którego wewnętrzny obraz ciała i osoby nie posiada trwałej reprezentacji umysłowej. W konsekwencji związek między psychiczną a somatyczną składową Jaźni (self) może być podatny na rozwój zaburzeń psychopatologicznych. W niniejszej pracy dążenie do nadmiernej stymulacji interpretowane jest jako próba przezwyciężenia trudności w odbieraniu bodźców z wnętrza ciała (interoceptywnych), bodźców zewnętrznych (eksteroceptywnych) oraz zaburzeń czucia głębokiego (propriocepcji). Silne pragnienie przyjęcia (głód) substancji psychoaktywnej i powtarzanie patologicznych zachowań są tu interpretowane jako próby zrekonstruowania schematu ciała, w sytuacji zaistniałego lub zagrażającego rozpadu Jaźni (self), poprzez zapamiętywanie bodźców (doznań zmysłowych) powstających przy użyciu obiektów nieożywionych, jedzenia lub substancji psychoaktywnych. W relacji z tymi obiektami 
nie jest jednak możliwe zwiększenie zdolności jednostki w zakresie symbolizowania, która to zdolność rozwija się jedynie w relacji między ludźmi. Metoda: W celu sprawdzenia tej hipotezy przeprowadzono analizę przypadku pacjenta ze współistniejącym uzależnieniem od substancji psychoaktywnych oraz zaburzeniami odżywiania. W badaniu opisano zintegrowaną metodę, polegającą na powtarzalnym - w ciągu 6 lat obserwacji - wykorzystaniu standardowych instrumentów psychologicznych, takich jak MMPI-2 (Minnesota Multiphasic Personality Inventory), EDI-2 (Eating Disorder Inventory) oraz TAS-20 (Toronto Alexithymia Scale), w połączeniu z interpretacją marzeń sennych bazującą na założeniach „teorii ludzkich narodzin" (Human Birth Theory) Massima Fagiolego. Zestawienie to miało służyć osiągnięciu większej rzetelności diagnostycznej, a także skonkretyzowaniu podejścia terapeutycznego. Wyniki: W ujęciu ilościowym pozytywna reakcja pacjenta na psychoterapię wyrażała się poprzez różnice $w$ wynikach zastosowanych skal psychologicznych, podczas gdy w analizie jakościowej manifestowała się zmianami w zakresie treści marzeń sennych. Wnioski: Uzyskane wyniki zachęcają do kolejnych badań nad istotą nadmiernego pragnienia (głodu) substancji psychoaktywnych w kontekście omawianej teorii ludzkich narodzin.

Słowa kluczowe: głód substancji psychoaktywnej (craving), świadomość sensoryczna Jaźni, psychoterapia, teoria ludzkich narodzin

\section{INTRODUCTION}

$\mathrm{T}$ he idea of a "basic fault of the Self," not defined yet in its biological and psychological origins, has been considered for a long time in psychopathological literature with regard to the research into paucisymptomatic psychosis. This deficit is manifested by a difficulty, with the configuration of the sensory consciousness of their Self reported by the person, accompanied by a difficulty in focusing on and conceptualising the reality together with experiences encountered in human relationships (Lorenzi and Pazzagli, 2006).

Similar observations have been reported in the field of psychodynamics, regarding eating disorder studies. In 1962, Bruch theorised that it is a "defective sense of the Self" which underlies eating disorders. It includes a wide range of deficits in conceptual development as well as disturbed body image and body awareness deficit. The inability to rely on their bodily sensations to define mentally the emotional states experienced in various life circumstances reported by patients with eating disorders is the basic element of the sense of inability to adjust their behaviour (Bruch, 1962). This split between the physiological and mental components of emotion is commonly observed also in the alexithymic (Taylor et al., 2007) and in patients with substance abuse disorders (Krystal and Raskin, 1970). It could also explain the significant comorbidity observed between substance abuse and eating disorders, which seems to involve about $40 \%$ of the population of sufferers (Eichen et al., 2016). The objective of this paper is to further the research into possible psychological factors underlying the deficit in the sensory consciousness of the Self, in which the internal image of the body and the person does not have a solid mental representation. In consequence, the relationship between the psychological and the somatic part of the Self seems vulnerable to psychopathological break-down. ${ }^{1}$ According to

${ }^{1}$ The concept of the Self as has been described in literature, is a polysemous concept and rich in stratifications. In this paper, I cite a series of authors who consider the alteration of the sensory consciousness of the Self to be a component of an eidetic nucleus at the base of dif- a widely shared view, it is possible to assume that this unusual and abnormal experience of one's own body could lead to a wide range of different psychopathological developments. Even though it may not be structurally prodromal of a psychotic onset, it may determine the risk of its occurrence - with a variable evolution depending on the vulnerability of the Self as well as the diachronic and synchronic quality of the relationship which will dynamically develop between the person and the human environment during lifetime (Lorenzi and Pazzagli, 2006). Hence, the utmost necessity arises of developing tools to diagnose and resolve this issue during a therapeutic treatment.

\section{THE THEORETICAL BACKGROUND}

The diagnostic process is carried out through an integrated method of clinical observation and evaluation, in which the crucial cognitive tool is the sensitivity of the therapist and their ability to assess the quality of the patient's mental reactions to the stimuli generated in the process of the evolution of the therapeutic relationship. This includes the dream activity, which is analysed and taken into consideration together with the results of standardised instruments. ${ }^{2}$ Based on many years of research and clinical experience, this study proposes the use of dream evaluation based on diagnostic criteria, as dream images can express pathological thoughts and dynamics, as well as the potential nucleus

ferent psychopathological expressions, even though they refer to different theoretical frame and they use different methods of observation and intervention. The concept of pre-reflective Self, to which I refer, coincides with the concept of the unconscious mind as it is defined in Massimo Fagioli's Human Birth Theory, which I describe in this article. The same applies to the concept of the inner image of the body which - unlike the authors as Bruch (1962), and in Lorenzi and Pazzagli (2006) - Fagioli construes to have a specific connotation, based on the dynamics defined in Human Birth Theory, through which the first "internal image" of the body and the person is formed and successively developed.

${ }^{2}$ For further deepening regarding this method cf.: Atzori E: Psychopathological effects of psychostimulant substances and psychotic onset: the difficult process of differential diagnosis between substance-induced psychosis and acute primary psychosis. Psychiatr Psychol Klin 2015; 15: 162-168. 
of fragility of the Self which may lead to the onset of psychosis. The possibility to perform the diagnostic activity with respect to the patient's unconscious mental processes is based on the following cardinal ideas:

- A dream image is a thought revealing itself through the non-verbal language of dream activity.

- Describing a dream image to the therapist, the patient is attempting to say something significant to them.

- It is fundamental to clarify how dreams are generated and how to comprehend their profound meaning.

The theoretical platform on which I rely in this article is known as Human Birth Theory (Teoria della Nascita), systematised by Massimo Fagioli in 1971. Fagioli rejected the body-mind dualism, theorising that human identity originates at birth, when the cortex is activated by the new and intense action of light on the retina and, simultaneously, non-conscious mental activity is generated. ${ }^{3}$ This non-verbal thinking, peculiar to humans, is defined as the "capability to imagine" (Fagioli, 2019, back cover), allowing for the existence of a thought which arises and expresses itself through images. Due to the newborn's inability to cope with the new and overwhelming physical stimulation coming from the external world, it is rendered non-existent in its mind through a physiological reaction of defense called "annulment pulsion" by Fagioli (Fagioli, 2016a). ${ }^{4}$ Fagioli claimed that, at birth, the annulment pulsion directed by the newborn at the non-human environment evokes in it what he defined as "vitality," which is the ability to be selectively oriented towards relationships with humans. It relates to them with emotion, ${ }^{5}$ and the forma-

\footnotetext{
${ }^{3}$ At birth, light represents a completely new stimulus for human beings. From recent research it emerges that there is a significant difference between the stimulation of the visual system present in the intrauterine and extrauterine environments. Depending on the type of tissue, the depth of the penetration of light wavelengths is less than $1 \mathrm{~mm}$ for blue $(400 \mathrm{~nm}), 2 \mathrm{~mm}$ for green $(514 \mathrm{~nm})$ and $6 \mathrm{~mm}$ for red $(630 \mathrm{~nm})$. The penetration of other light wavelengths is below $480 \mathrm{~nm}$ and is not conducted to the uterus (Fargnoli and Gatti, 2015). Fagioli's birth theory strongly asserts the biological origin of the psyche. This theory, formulated 48 years ago, has recently been corroborated by medical research. Neonatologists now know that the newborn can only survive out of the uterus if the connections between the retina and the visual cortex are formed (at about the twenty-fourth week of gestation). Recent neurophysiological research has provided information on how the brain functioning is thoroughly modified at birth through the induction of Immediate Early Genes which are not active in the foetus and with a short time of activation, can be aroused only by light (Vandewalle et al., 2013).

${ }^{4}$ The physical conditions observable in the newborn in its first seconds of life, when its musculoskeletal apparatus is atonic and its cardiac signal is considerably reduced compared to the previous foetal cardiac signal (Dawson, 2010), could be considered as a phenomenal expression of this defence response. Moreover, a confirmation of the existence of this reaction is provided by the activation of the reticular thalamic nucleus (RTN), a diencephalic structure located in the web of GABAergic inhibitory neurons which cover the thalamus. This can last up to a second and a half (Vezzosi and Pettini, 2015). Fagioli chose the term "pulsion" instead of "drive" because he considered it more adequate to describe a non-conscious mental activity (Fagioli, 2016. Unpublished raw data).

${ }^{5}$ In Fagioli's view, "vitality" finds its precursor in the biological "capability to react" to sensory stimuli, which allows the newborn to survive and which is closely linked to the first thalamocortical and corticocortical connections formed at 23-24 postconceptional weeks (PCW).
}

tion of the first "internal image" of their body, because it is indissolubly linked to the "memory of the sensations" experienced through the cutaneous contact between the foetus and the amniotic fluid. ${ }^{6}$ This memory constitutes, a Primal Self which is not only the first "sense of oneself" but also an intuition-hope that there is another human being which can relate to the infant, responding to its needs to survive and to develop. This Primal Self is, therefore, a first non-fragmented image, constituted by a memory of the homeostatic sensations, combined with the certainty of finding another human being. According to Fagioli's theory, an adult who responds constantly and correctly not only to the physiological needs of the infant's developing body, but also to the peculiar requirements of its psychological development, will, in the process of breastfeeding and nursing, convey the sense of love and protection, at each interaction, allowing for the development of the "capability to imagine" (Fagioli, 2019, back cover), which originates at birth (Fagioli, 2016a). The development of this capability will be expressed by a fantasy which will allow the infant of about ten months to mentally draw a line around his/her face reflected in the mirror (Fagioli, 2016b). Thus, the infant can become aware of an image of him/herself which is not a reproduction of a previously seen conscious figure, but an image-idea of him/herself (Fagioli, 2014) built on the sensitivity present at birth and developed through a responsive relationship (Fagioli, 2017). ${ }^{7}$ This knowledge of oneself, stemming from sensitivity, will be perfected with the development of speech, which will allow for its conscious definition (Fagioli, 2017). However, if the caregiver is not responsive to the infant's needs and requirements, its development takes an altogether different trajectory (Fagioli, 2019).

For a recent analysis of the literature about neurofunctional correlates between physiological findings and the Human Birth Theory cf. Maccari S, Polese D, Reynaert ML et al.: Early-life experiences and the development of adult diseases with a focus on mental illness: the Human Birth Theory. Neuroscience 2017; 342: 232-251.

${ }^{6}$ In Human Birth Theory Fagioli asserted that the embryo and the foetus are biological existences without psychic activity. In spite of that, during the last months of gestation the foetus is presumed to develop what Fagioli named a prepsychic "libidic capability," specifically caused by its cutaneous contact with the amniotic liquid. Fagioli claimed that this "libidinal" experience could leave traces which may be "stored" at a subcortical level. For a corroboration of this statement cf. Gonzalez-Gonzalez NL, Suarez MN, Perez-Piñero B et al.: Persistence of fetal memory into neonatal life. Acta Obstet Gynecol Scand 2006; 85: 1160-1164. According to Massimo Fagioli at birth, this prepsychic libidinal storage, through the activation of the somatosensory cortex, becomes a mental content, a memory of homeostatic sensations that constitutes a first indefinite "image" of itself.

${ }^{7}$ The dynamic of integration of somatic experiences with inputs coming from the environment integrating vestibular, proprioceptive, tactile and visual signals, is thought to be at the core of an intrinsic form of self-awareness and sense of selfhood (Damasio, 1999). It is also possible to assert that the perception of the body is closely linked to the quality of emotional events that occurs in human relationships (Damasio, 1999; Gentsch et al., 2016). Thus, body representations are the result of a global memory of what is perceived and lived on an affective and sensorial base in interpersonal relationship. According to Fagioli's theorisation it is possible to consider that the memory is a creation of an image which changes the figure perceived (Fagioli, 2009). 
The caregiver who has not developed their own human reality during their lifetime and has lost their affections due to disappointments in human relationships, may not be able to respond to the newborn's requests at different levels, which can range from failing to respond to the psychological "requirements " (Fagioli, 2019, p. 19) connected with the relationship, to, as Bruch (1962) and Selvini Palazzoli (1974) observed, the inability to meet its physiological needs. According to Fagioli, in such a case, the mental reaction of the infant to the maternal deficiency is a defense reaction directed at cancelling the mental reality of the caregiver, who is perceived as violent because of their non-responsiveness. Together with the progressive disappearance of the image of the object due to the annulment pulsion, the image of itself in relationship with it becomes less founded and so does the memory of the sensations experienced through the contact between foetal skin and amniotic liquid (Fagioli, 2015. Unpublished raw data). In this way, the infant progressively loses the intrapsychic and interrelation sensitivity, resulting in the loss of the body sensitivity enabling it to feel him/herself and, at about ten months, to recognise him/herself through the mental image of his/her face reflected in the mirror. The somatic part of the Self (somatic Self) which emerges is affected in its mental configuration and may lead to an altered perception of the body scheme, which is evident in some clinical manifestations of eating disorders, such as anorexia nervosa, bulimia nervosa, as well as in some forms of obesity resulting from binge eating (Atzori, 2018b; Holmes et al., 2015; Mancuso et al., 2016). It is less evident but still present in substance abuse (Krystal, 1982, 1962). These difficulties appear indissolubly linked to an impaired ability to come into sensitive contact with human beings and understand them. According to Fagioli's theory, they result from a lack of affectivity. The pulsional dynamic caused by a disappointing relationship leads to a loss of the "capability to imagine" (Fagioli, 2019, back cover), thus affecting the possibility to develop the symbolic and representative thinking, as it is often described in literature regarding eating disorders and substance abuse. This loss, of various levels of severity, may produce different forms of fragility of the Self and various psychopathological manifestations observed in clinical experience such as, in severe cases, operational and concrete thinking, various dissociative states of consciousness and "contained" and latent dissociative forms of thinking, which can be detected in dream activity.

\section{METHODS}

This case study was conducted in the period of six years on an Italian female patient of 25, with a high school degree, employed and unmarried. The standardised assessment was conducted with the use of MMPI-2 (Minnesota Multiphasic Personality Inventory), ASI (Addiction Severity Index), TAS-20 (Toronto Alexithymia Scale), EDI-2 (Eating psychotherapy, before the beginning of treatment. It was repeated after 6 years of treatment. This standardised evaluation was accompanied, for the whole period of 6 years, by the interpretation of dreams based on the theoretical platform of Massimo Fagioli's Human Birth Theory, in order to achieve greater diagnostic certainty as well as more effective therapeutic treatment. The method of treatment was psychodynamic psychotherapy based on Human Birth Theory. The psychotherapy, conducted in the form of a session of fifty minutes once a week, started in an Eating Disorders Day Unit. After six months, the treatment was transferred to a private practice, with the same therapist and based on the same psychotherapeutic procedure. In this case study of comorbidity of eating disorder and substance abuse I treat sensation seeking as an attempt to overcome a proprioceptive, an interoceptive and an exteroceptive difficulty.

Consequently, I propose an interpretation for the craving and the repetition of the pathological behaviour as an attempt to reconstruct the body scheme in a Self which is fragmented or at a risk of fragmentation through the memory of the sensations experienced using an inanimate object, food or psychotropic substances. In relationship with them an increase in symbolic capability and internal fantasy is impossible, as it is achievable only through a human relationship. In the following single case study I describe some of the ways in which sensations are sought to protect a fragile Self against fragmentation as well as the patient's response to therapeutic treatment based on the interpretation of non-conscious psychological dynamics underlying the risk of the disintegration of the Self.

\section{CASE REPORT}

V., 25 years old, started her therapeutic treatment in an Eating Disorders Day Unit. After discharge, she continued the psychotherapy treatment started in the clinic in private practice sessions. During the clinical interviews, she reported profound difficulties in relationships with peers as well as anxiety which made it difficult to work and carry out daily activities. She reported feelings of self-inefficacy rooted in the difficulties perceived in understanding people's propositions in relationships. At the beginning of the therapeutic treatment, she lived with a man with whom she occasionally used cocaine and abused alcohol. She ended the relationship after 2 years of psychotherapy. From the ASI interview, administered at the admission of the patient to psychotherapy, before the beginning of treatment, it followed that V. started cannabinoid abuse when she was about 15 years old. She used cannabis with friends, in the amount of about 4 doses per week. At about 17, V. gradually increased cannabinoid abuse although it was not yet continuous. The abuse became intense when she was 20 years old. In that period, the patient started to smoke alone and at work. At 21, until the age of 24, she increased cannabis consumption to 8 doses per day and, at the same 
time, she started using cocaine with her boyfriend and her friends - a couple of times per week. In discotheques, she took MDMA and amphetamines. At about the age of 24, with a new boyfriend, she increased the consumption of cocaine to 4 times per week. After splitting with him, she intensified the abuse of cocaine. It became the solitary stimulant, preferred to cannabis, consumed at the rate of 3 grams per day. Afraid of the intensification of cocaine abuse she went back to cannabis, keeping the consumption at about 6 doses per day. During her adolescence, she developed an alcohol habit combined with the use of other substances for their disinhibiting effect rendering relationships easier. Eating disorders also developed in adolescence, with binge eating which would periodically make V.s weight exceed the upper limit defined by body mass index, followed by periods of food restriction, in which she quickly reached the lower BMI limit or went slightly below it. MMPI-2, performed at the admission of the patient to psychotherapy before the beginning of treatment, yielded a depressive profile.

V. described herself as overwhelmed by problems, desperate, obsessed by a sense of guilt and feelings of unworthiness and inadequacy. She felt downhearted, and described herself as slow in thought and in action. She described a series of physical dysfunctions and a wide variety of somatic disorders $(\mathrm{D} 3=74)$. Among the critical items reported in the questionnaire, there were ideas of death and suicidal ideations $(\mathrm{D}=90)$. She felt uncomfortable in social relationships (D1 $=81)$ as well as in personal relationships, in which she experienced a sense of failure and a constant feeling of internal void $(\mathrm{Pd}=70)$. Moreover, she felt misunderstood, isolated and confined $(\mathrm{Pd}=4)$. She experienced intense anxiety mixed with continuous insecurity $(\mathrm{Pt}=75)$. This clinical profile was also confirmed by the results of EDI-2 test conducted at the admission of the patient to psychotherapy before the beginning of treatment, in which the Interoceptive awareness $\left(p=52.8^{\text {th }}\right)$, Interpersonal distrust $\left(p=67^{\text {th }}\right)$, Ineffectiveness $\left(p=76^{\text {th }}\right)$, and Bulimia $\left(\mathrm{p}=40^{\text {th }}\right)$ scales indicated an intermediate level of severity. It was confirmed by results from the TAS-20 $(\mathrm{p}=77)$ test, administered at the admission of the patient to psychotherapy before the beginning of treatment, which exceeded the cut off $(\mathrm{p}=61)$. The results on the F1 scale $(\mathrm{p}=34)$ regarding the difficulties in identifying emotional states seemed to correlate with the Interpersonal distrust scale of EDI-2.

In the first dream by which the patient tried to represent after 1 year of psychotherapy - the problem with the sensory consciousness of her Self, she saw herself in the mirror but did not recognise her face because it was deformed, especially her upper lip, which was split in the middle.

During the second year of treatment, she dreamt that she rejected a man who wanted a sexual relationship because she felt ashamed of her pubic hair.

After 6 years of treatment the patient dreamt that she rejected her mother and asked her to leave her home.
Afterwards, she dreamt that her face was harmonious and she had a dental brace in her mouth. ${ }^{8}$

Immediately after her telling of these dreams I repeated the EDI-2, TAS-20 and ASI tests.

In EDI-2, the score in Interoceptive awareness was the $13.2^{\text {th }}$ percentile, in Interpersonal distrust it was the $25^{\text {th }}$ percentile, in Ineffectiveness it was the $68^{\text {th }}$ percentile, while in Bulimia it was the $18^{\text {th }}$ percentile. In TAS-20 the score was 69 . At the same time, cannabis use amounted to 1 dose per day.

\section{DISCUSSION}

I propose that with the dream image of the cleft palate and the split superior lip, the patient tried to represent the lack of integration perceived between the somatic Self and the mental Self resulting from the loss of intrapsychic and interpersonal sensitivity, which I hypothesise is at the origin of compulsive self-stimulation manifested by binge eating and substance abuse. This was caused by repeated annulment pulsion directed towards her disappointing parents: the non-responsive mother and the father who separated from his wife when the patient was 3 years old. He did not care for her anymore and disappeared from her life. In adolescence, this fragility of the Self became evident when the physiological changes to the body exposed her to new crisis and she started to menstruate. She found her mature body shameful and during the psychotherapy she represented this feeling through the dream in which she rejected a man who wanted to have a sexual relationship with her because she felt ashamed of her pubic hair. Loss of sensitivity resulted in her non-receptivity and inability to evolve in human relationships. This immobility was addressed and gradually overcome through repeated interpretation of the annulment pulsion directed outwards. ${ }^{9}$ At a certain point of the treatment, this practice allowed V. to represent her psychotherapist and the relationship with her in her dreams. Another human being gradually became more understandable for her, which allowed her to restore the process of individuation, impossible in the past due to her parents' failure, represented in the dream in which she rejected her mother and asked her to leave her home. Furthermore,

\footnotetext{
${ }^{8}$ I chose to report these dreams out of the whole oneiric production of the patient during the six years of treatment because I found them of particular relevance for this research, and strongly representative of the substantial complexity of the changes taking place in the dream activity which accompanied the patient's telling about and working on her life, her modality of relationship and her identity.

${ }_{9}$ The interpretation of the pulsional dynamic which allows the patient to realise a disappearance fantasy towards the personal pathological modality of relationships, is the specific factor of the therapeutic process which is considered fundamental in this work. Another aspect of the therapeutic process, treated as fundamental in this paper, consists in the human reality of the therapist, and, specifically, his or her sensitivity. This aspect, defined in literature as a non-specific factor of cure, is considered to be the element which, together with the clinical experience and the knowledge of the theoretical principles of reference, determines the correctness and the effectiveness of the therapeutic treatment in all its complexity.
} 
after 6 years of psychotherapy she was finally able to represent her face as harmonious and not deformed. In the dream, although her face was undeformed, she had a dental brace. Considering that the patient was not in dental treatment I presume that this image was a symbolic representation of the meaning and objective of the therapeutic treatment, the progress of psychotherapy towards a dynamic definition of personal identity. The medical treatment (dental brace) is aimed here at defining and harmonising her face (her personal identity). These results converged with the results of the retest after 6 years of treatment, which reported a significant reduction in symptoms. In the TAS-20, there was a reduction in score from 77 to 69 ; in the EDI-2 there was a reduction in the Interoceptive awareness the score went down from the $52.8^{\text {th }}$ percentile to $13.2^{\text {th }}$; in the Interpersonal distrust scale the score decreased from the $67^{\text {th }}$ percentile to $25^{\text {th }}$; in the Ineffectiveness scale score, from the $76^{\text {th }}$ percentile to $68^{\text {th }}$; in the Bulimia scale score from the $40^{\text {th }}$ percentile to $18^{\text {th }}$; meanwhile, a reduction in cannabis consumption took place, from 6 doses per day to 1.

In literature, it is reported that a high score on the Interoceptive awareness scale in EDI-2 is predictive of limited response to treatment (Garner, 2015). In this case, however, it is possible to assume that the patient's quantitatively positive reaction to the psychotherapy was expressed by the change in scale scores (test-retest), while her qualitatively positive reaction was expressed through the change in dream activity and in the subjective experience verbalised by the patient. Furthermore, the correlation between the variations in the Interoceptive awareness, Bulimia and Interpersonal distrust scale scores, combined with the reduction in cannabinoid consumption and the development of symbolic and representative thinking expressed through a qualitative change in dream activity, seems to corroborate the interpretative hypothesis about sensation seeking and craving proposed in this paper.

The internal validity of this study is limited due to the fact that, in psychotherapy, it is practically impossible to create the conditions allowing for artificial manipulation of variables, which is possible in a "real experimental research design" in which the experimenter maintains all the constant variables and manipulates the independent variable (Dazzi et al., 2006). In single case designs, quantitative research concentrates on the attempt to establish a relationship between two or more variables, basing the research on a different causal logic: the link between the variables is demonstrated by their co-occurrence instead of their experimental manipulation (Lingiardi, 2006). Hence, in this case study, I analysed the relationship of co-occurrence between the progression of the interpretations of the annulment pulsion (considered as a specific factor of cure), modulated by the personality and the sensitivity of the therapist (considered as a non-specific factor of cure), the qualitative change in the patient's modality of the relationship and in her dream activity, and the significant reduction in the symptoms reported by the patient after 6 years of treatment, measured with standardised instruments. The functioning of the patient's personality as well as the process and the outcome of the treatment are examined from the perspective of the principle of congruency "Patient-TherapistOutcome" (Strupp et al., 1988, p. 7). Nonetheless, this study allows to formulate logical inferences about the modalities causing change in the variables considered, but not to define any causal relationship between them. Nevertheless, given that one of the characteristics of fortuity is - by definition - its randomness, I expect to replicate the observations integrating the qualitative and quantitative evaluations performed with the use of standardised instruments in an intensive and longitudinal study aimed at progressively decreasing the risk that a given co-occurrence is accidental (Del Corno, 2006).

Another limitation of this study is the incomparability of the concept of sensation seeking (primary hypothesis), and the interpretation of craving (secondary and derived hypothesis) which I propose in this paper as my own original hypothesis, with other hypotheses used in literature. For this reason, even though the reviewers of the single case approach noticed that generalisation of results to a specific statistical population is a critical specification for an intensive study (Chassan, 1979), in order to increase the external validity of this study (Fonagy, 2002; Kazdin, 1994), I expect to be able to validate my interpretative hypothesis about sensation seeking and craving proposed in this paper, in the course of further longitudinal single case studies, including the present one, comparative studies and extensive research designs with direct replications, systematic replications (with different therapists and in different contexts) (Sidman, 1960), and in different clinical research application domains (Popper, 2010) such as gambling, gaming and internet addiction. ${ }^{10}$

\section{Conflict of interest}

The author does not report any financial or personal affiliations to persons or organisations that could adversely affect the content of this publication or claim to have rights thereto.

\section{Acknowledgements}

Thanks to Professor M. Fagioli, who died in 2017, and on November 20th 2010 during the meeting of the Editorial Board of the "Journal of Psychiatry and Psychotherapy" "Il sogno della farfalla" allowed me to focalise the role that the loss of intrapsychic, interrelation and physical sensitivity could have in sensation seeking. It constituted the start point

\footnotetext{
${ }^{10}$ I presented other attempts to control the hypothesis about sensation seeking and craving that I proposed in this paper in: Atzori E: The alteration of the sensory consciousness of the Self as a trigger mechanism determining binge in Eating Disorders. A comparison between two single case studies. E-Poster presented at EPA 2018, $26^{\text {th }}$ European Congress of Psychiatry, 2018b, March, Nice, France; and in: Atzori E: The alteration of the sensory consciousness of the Self as a trigger mechanism determining a craving in gambling and eating disorders. A pilot study. Selected Oral Presentation, WADD $2^{\text {nd }}$ World Congress, 2018a, October, Florence, Italy. Abstract published in Heroin Addict Relat Clin Probl 2018; 20 (2): 11.
} 
of a research still in progress, that enabled me to formulate the hypothesis about the psychic factors at the base of sensation seeking and craving that I propose in this paper.

Thanks to Dr. A. Masini, who in a private review of a previous work, pointed out the importance to clarify the substantial difference between the lexical formulation of "inner image" of the body in Fagioli's Human Birth Theory and in other authors as Pazzagli (2006), and Bruch (1962).

\section{References}

Atzori E: Psychopathological effects of psychostimulant substances and psychotic onset: the difficult process of differential diagnosis between substance-induced psychosis and acute primary psychosis. Psychiatr Psychol Klin 2015; 15: 162-168.

Atzori E: The alteration of the sensory consciousness of the Self as a trigger mechanism determining a craving in gambling and eating disorders. A pilot study. Selected Oral Presentation, WADD $2^{\text {nd }}$ World Congress, 2018a, October, Florence, Italy.

Atzori E: The alteration of the sensory consciousness of the Self as a trigger mechanism determining binge in Eating Disorders. A comparison between two single case studies. E-Poster presented at EPA 2018, 26 ${ }^{\text {th }}$ European Congress of Psychiatry, 2018b, March, Nice, France.

Bruch H: Perceptual and conceptual disturbances in anorexia nervosa. Psychosom Med 1962; 24: 187-194.

Chassan JB: Research Design in Clinical Psychology and Psychiatry. $2^{\text {nd }}$ ed., Appleton-Century-Crofts, New York 1979.

Damasio AR: The Feeling of What Happens: Body and Emotion in the Making of Consciousness. Harcourt, San Diego 1999 (trad. it. Emozione e coscienza, Adelphi, Milano 2000).

Dawson JA, Kamlin COF, Wong C et al.: Changes in heart rate in the first minutes after birth. Arch Dis Child Fetal Neonatal Ed 2010; 95: F177-F181.

Dazzi N, Lingiardi V, Colli A (eds.): La ricerca in psicoterapia. Modelli e strumenti [The Research in Psychotherapy. Models and Instruments]. Raffaello Cortina, Milano 2006.

Del Corno F: Come leggere e capire un articolo di ricerca in psicoterapia [How to read and understand an article in psychotherapy research]. In: Dazzi N, Lingiardi V, Colli A (eds.): La ricerca in psicoterapia. Modelli e strumenti [The Research in Psychotherapy. Models and Instruments]. Raffaello Cortina, Milano 2006: 65-90.

Eichen DM, Chen EY, Schmitz MF et al.: Addiction vulnerability and binge eating in women: exploring reward sensitivity, affect regulation, impulsivity \& weight/shape concerns. Pers Individ Dif 2016; 100: 16-22.

Fagioli M: Death Instinct and Knowledge. $1^{\text {st }}$ English ed., translated by Marcella Matrone, Lasino d’oro, Rome 2019.

Fagioli M: Il linguaggio articolato nuovo [The new speech language]. Left 2017: 64-65.

Fagioli M: Left 2009. L'asino d’oro, Rome 2009.

Fagioli M: Left 2014. Lasino d'oro, Rome 2014.

Fagioli M: L'istante della luce è esistenza della vitalità [The instant of the light is the existence of the vitality]. Left 2016a: 64-65.

Fagioli M: Ricreare la realtà non materiale passata è fantasia [To recreate the passed non material reality is fantasy]. Left 2016b: 64-65.

Fargnoli F, Gatti MG: The birth of the human mind: a new integrative model of functional activation of the cortex in the newborn based on Massimo Fagioli's Human Birth Theory. $19^{\text {th }}$ International Congress of the International Society for Psychological and Social Approaches to Psychosis - From DNA to Neighborhood: Relationship and Experience in Psychosis. An International Dialogue, New York, 2015, March. Il sogno della farfalla; 4: 106-112.
Fonagy P: An Open Door Review of Outcome Studies in Psychoanalysis. $2^{\text {nd }}$ ed., International Psychoanalytic Association, New York 2002.

Garner DM: Eating Disorder Inventory-3. th $^{\text {th }}$ ed., Giunti O. S., Firenze 2015.

Gentsch A, Crucianelli L, Jenkinson P et al.: The touched self: affective touch and body awareness in health and disease. In: Olausson H, Wessberg J, Morrison I (eds.): Affective Touch and the Neurophysiology of CT Afferents. Springer, New York 2016: 355-384.

Gonzalez-Gonzalez NL, Suarez MN, Perez-Piñero B et al.: Persistence of fetal memory into neonatal life. Acta Obstet Gynecol Scand 2006; 85: 1160-1164.

Holmes M, Fuller-Tyszkiewicz M, Skouteris H et al.: Understanding the link between body image and binge eating: a model comparison approach. Eat Weight Disord 2015; 20: 81-89.

Kazdin AE: Methodology, design, and evaluation in psychotherapy research. In: Bergin AE, Garfield SL (eds.): Handbook of Psychotherapy and Behavior Change. $4^{\text {th }}$ ed., John Wiley \& Sons, New York 1994: 19-71.

Krystal H: Adolescence and the tendencies to develop substance dependence. Psychoanal Inq 1982; 2: 581-617.

Krystal H: The opiate-withdrawal syndrome as a state of stress. Psychiatr Q Suppl 1962; 36: 53-65.

Krystal H, Raskin HA: Drug Dependence: Aspects of Ego Function. Wayne State University Press, Detroit 1970.

Lingiardi V: La ricerca single-case [Single-case research]. In: Dazzi N, Lingiardi V, Colli A (eds.): La ricerca in psicoterapia. Modelli e strumenti [The Research in Psychotherapy. Models and Instruments]. Raffaello Cortina, Milano 2006: 123-147.

Lorenzi P, Pazzagli A: Le psicosi bianche [White Psychosis]. Franco Angeli, Milano 2006.

Maccari S, Polese D, Reynaert ML et al.: Early-life experiences and the development of adult diseases with a focus on mental illness: the Human Birth Theory. Neuroscience 2017; 342: 232-251.

Mancuso SG, Phillipou A, Rossell SL et al.: Body image disorders in woman. In: Castle DJ, Abel KM (eds.): Comprehensive Women's Mental Health. Cambridge University Press, Cambridge 2016: 197-207.

Popper KR: Logica della scoperta scientifica [The Logic of Scientific Discover]. $8^{\text {th }}$ ed., Einaudi, Torino 2010.

Selvini Palazzoli M: Self-Starvation: From the Intrapsychic to the Transpersonal Approach to Anorexia Nervosa. Chaucer, London 1974.

Sidman M: Tactics of Scientific Research: Evaluating Experimental Data in Psychology. Basic Books, New York 1960.

Strupp HH, Schacht TE, Henry WP: Problem-treatment-outcome congruence: a principle whose time has come. In: Dahl H, Kächele H, Thomä H (eds.): Psychoanalytic Process Research Strategies. Springer, New York 1988: 1-14.

Taylor GJ, Bagby RM, Parker JDA: Disorders of Affect Regulation: Alexithymia in Medical and Psychiatric Illness. Cambridge University Press, Cambridge 1997 (trad. it. I disturbi della regolazione affettiva: L'alessitimia nelle malattie mediche e psichiatriche. Giovanni Fioriti, Roma 2007).

Vandewalle G, Collignon O, Hull JT et al.: Blue light stimulates cognitive brain activity in visually blind individuals. J Cogn Neurosci 2013; 25: 2072-2085.

Vezzosi G, Pettini M: Massimo Fagioli's Birth Theory: a scientific theory of human reality. $19^{\text {th }}$ International Congress of the International Society for Psychological and Social Approaches to Psychosis - From DNA to Neighborhood: Relationship and Experience in Psychosis. An International Dialogue, New York, 2015, March. Il sogno della farfalla; 4: 112-116. 